\title{
WIKIPEDIA
}

\section{Retractions in academic publishing}

In academic publishing, a retraction is the action by which a published paper in an academic journal is removed from the journal. Online journals typically remove the retracted article from online access.

\section{Contents}

\section{Procedure}

\section{History}

\section{Notable retractions}

Retraction for error

Retraction for fraud or misconduct

Retraction over data provenance

Retraction over public relations issues

\section{See also}

\section{References}

\section{Further reading}

\section{Procedure}

A retraction may be initiated by the editors of a journal, or by the author(s) of the papers (or their institution). Retractions are typically accompanied by a retraction notice written by the editors or authors explaining the reason for the retraction. Such notices may also include a note from the authors with apologies for the previous error and/or expressions of gratitude to persons who disclosed the error to the author. ${ }^{[1]}$

A lesser withdrawal of content than a full retraction may be labelled a correction. There have been numerous examples of retracted scientific publications. Retraction Watch provides updates on new retractions, and discusses general issues in relation to retractions. ${ }^{[2][3][4]}$

\section{History}

A 2011 paper in the Journal of Medical Ethics attempted to quantify retraction rates in PubMed over time to determine if the rate was increasing, even while taking into account the increased number of overall publications occurring each year. ${ }^{[5]}$ The author found that the rate of increase in retractions was greater than the rate of increase in publications. Moreover, the author notes the following:

"It is particularly striking that the number of papers retracted for fraud increased 
more than sevenfold in the 6 years between 2004 and 2009. During the same period, the number of papers retracted for a scientific mistake did not even double..." (p. 251). [5]

Although the author suggests that his findings may indeed indicate a recent increase in scientific fraud, he also acknowledges other possibilities. For example, increased rates of fraud in recent years may simply indicate that journals are doing a better job of policing the scientific literature than they have in the past. Furthermore, because retractions occur for a very small percentage of overall publications (fewer than 1 in 1,000 articles ${ }^{[6][7]}$ ), a few scientists who are willing to commit large amounts of fraud can highly impact retraction rates. For example, the author points out that Jan Hendrik Schön fabricated results in 15 retracted papers in the dataset he reviewed, all of which were retracted in 2002 and 2003, "so he alone was responsible for $56 \%$ of papers retracted for fraud in 2002-2003" (p 252).[5]

During the COVID-19 pandemic, academia had seen a quick increase in fast-track peer-review articles dealing with SARS-CoV-2 problems. As a result, a number of papers have been retracted due to quality and/or data issues, leading many experts to ponder not just the quality of peer review but also standards of retraction practices. $[8]$

Retracted studies may continue to be cited. This may happen in cases where scholars are unaware of the retraction, in particular when the retraction occurs long after the original publication.[9]

\section{Notable retractions}

\section{Retraction for error}

- 2013 - Study on the Mediterranean diet published in New England Journal of Medicine and widely covered by media was retracted due to unreported non-random assignments. This was part of a larger effort verifying proper randomization in thousands of studies by anesthesiologist John Carlisle, who found problems in about $2 \%$ of those analyzed.[6]

- 2012 - Séralini affair - Article suggesting reported an increase in tumors among rats fed genetically modified corn and the herbicide RoundUp retracted due to criticism of experimental design. According to the editor of the journal, a "more in-depth look at the raw data revealed that no definitive conclusions can be reached with this small sample size".[10]

- 2003 Retracted Science article on ecstasy. See Retracted article on neurotoxicity of ecstasy.

- Frank Cameron Jackson, supporter of the theory of epiphenomenalism, retracted his position due to an error in reasoning. ${ }^{[11]}$

\section{Retraction for fraud or misconduct}

- 2021 An article studying open source community by Quushi Wu and Kangjie Lu at University of Minnesota was withdrawn after Linux Foundation found out that researchers submitted patches for Linux kernel with intentional bugs without obtaining appropriate consent. [12][13]

- 20175 articles by Brian Wansink at Cornell University came under scrutiny in the field of consumer behavior and marketing research after peers pointed out inconsistencies in data in papers after Wansink had written a blog post about asking a graduate student to 
"salvage" conclusions. Cornell University has since investigated the issues and in 2018 he was found by a University investigatory committee to have committed academic misconduct and resigned. [14][15][16] Wansink has since had 18 of his research papers retracted as similar issues were found in other publications. [17][18][19]

- 2014 An article by Haruko Obokata et al. on STAP cells, a method of inducing a cell to become a stem cell, was proven to be falsified. Originally published in Nature, it was retracted later that year. It generated much controversy, and after an institutional investigation, one of the authors committed suicide.[20][21]

- 2011 Retraction: Enhanced Inhibition of Tumour Growth and Metastasis, and Induction of Antitumour Immunity by IL-2-IgG2b Fusion Protein. Scandinavian Journal of Immunology, 73: 266. by Budagian V, Nanni P, Lollini PL, Musiani P, Di Carlo E, Bulanova E, Paus R, Bulfone-Paus S. 2002*[22]

- 2011 Anil Potti, formerly a cancer researcher at Duke University. Eight journal articles authored by Anil Potti and others that describe genomic signatures of cancer prognosis and predictors of response to cancer treatment were retracted in 2011 and 2012. The retraction notices generally state that the results of the analyses described in the articles could not be reproduced. In November 2015, the Office of Research Integrity (ORI) found that Potti had engaged in research misconduct[23]

- 2010 A 1998 paper by Andrew Wakefield proposing that the MMR vaccine might cause autism, which was responsible for the MMR vaccine controversy, was retracted because "the claims in the original paper that children were "consecutively referred" and that investigations were "approved" by the local ethics committee have been proven to be false."[24]

- 2009 Numerous papers written by Scott Reuben from 1996 to 2009 were retracted after it was discovered he never actually conducted any of the trials he claimed to have run.

- 2007 Retraction of several articles written by social psychologist Jennifer Lerner and colleagues from journals including Personality and Social Psychology Bulletin and Biological Psychiatry.

- 2006 Retraction of Patient-specific embryonic stem cells derived from human SCNT blastocysts. written by Hwang Woo-Suk. Fabrications in the field of stem cell research led to 'indictment on embezzlement and bioethics law violations linked to faked stem cell research'.

- 2003 Numerous articles with questionable data from physicist Jan Hendrik Schön from many journals including both Science and Nature are retracted.

- 2002 Retraction of announced discovery of elements 116 and 118. See Livermorium, Victor Ninov.

- 2002 Retracted article on dopaminergic neurotoxicity of MDMA

- 1991 Thereza Imanishi-Kari, who worked with David Baltimore, published a 1986 article in the journal Cell. Margot O'Toole, a postdoctoral researcher for Imanishi-Kari publicized Imanishi-Kari's scientific misconduct. After a major investigation, Baltimore was finally forced to issue a retraction in 1991 when the National Institutes of Health concluded that data in the 1986 Imanishi-Kari article had been falsified. In 1996, an expert panel appointed by the federal government cleared Imanishi-Kari of misconduct, finding no evidence of scientific fraud.

- 1982 John Darsee. Fabricated results in the Cardiac Research Laboratory of Eugene Braunwald at Harvard in the early 1980s. Initially thought to be brilliant by his boss. He was caught out by fellow researchers in the same laboratory. 


\section{Retraction over data provenance}

- 2020 On 22 May 2020, during the COVID-19 pandemic, an article was published in The Lancet, claiming to find evidence, based on a database of 96032 COVID-19 patients, that hydroxychloroquine and chloroquine increase the chance of patients dying in hospital and increase the chance of ventricular arrhythmia. ${ }^{[25]}$ Medical researchers and newspapers expressed suspicions about the validity of the data, provided by Surgisphere, founded by one of the authors of the study. [26] The article was formally retracted by 4 June 2020, on request by the lead author Mandeep Mehra.[27][25]

\section{Retraction over public relations issues}

- 2020 was retracted paper on police killings and race[28]

- 2016 On March 4, 2016, an article in PLOS ONE about the functioning of the human hand ${ }^{[29]}$ was retracted due to outrage on social media over a reference to "Creator" inside the paper (\#CreatorGate). [30]

- 1896 Jose Rizal was said to have issued a letter of retraction regarding his novels and other published articles against the Roman Catholic Church, see José Rizal: Retraction controversy.

\section{See also}

- Fabrication (science)

- Post-publication peer review

- Retraction Watch

- Scientific misconduct

- Sokal affair\#Similar incidents

- Erratum

- Correction (newspaper)

\section{References}

1. Vuong, Q.-H. (2020). "The limitations of retraction notices and the heroic acts of authors who correct the scholarly record: An analysis of retractions of papers published from 1975 to 2019" (https://doi.org/10.1002\%2Fleap.1274). Learned Publishing. 33. doi:10.1002/leap.1274 (https://doi.org/10.1002\%2Fleap.1274).

2. Kleinert, Sabine (2009). "COPE's retraction guidelines". The Lancet. 374 (9705): 1876-7. doi:10.1016/S0140-6736(09)62074-2 (https://doi.org/10.1016\%2FS0140-6736\%2809\%2962 074-2). PMID 19962558 (https://pubmed.ncbi.nlm.nih.gov/19962558). S2CID 22313713 (htt ps://api.semanticscholar.org/CorpusID:22313713).

3. The retraction war - Scientists seek demigod status, journals want blockbuster results, and retractions are on the rise (https://aeon.co/magazine/philosophy/are-retraction-wars-a-sign-t hat-science-is-broken/) (December 2014), Jill Neimark, Aeon

4. Strauss, Stephen (April 7, 2011). "Searching for truth in published research" (http://www.cbc. ca/news/technology/story/2011/04/04/f-vp-strauss-truth-published-research.html). CBC News. 
5. Steen, R. G. (2011). Retractions in the scientific literature: Is the incidence of research fraud increasing? Journal of Medical Ethics, 37(4), 249-253. doi: 10.1136/jme.2010.040923.

6. Errors Trigger Retraction Of Study On Mediterranean Diet's Heart Benefits (https://www.npr. org/sections/health-shots/2018/06/13/619619302/errors-trigger-retraction-of-study-on-medit erranean-diets-heart-benefits)

7. "Two Cheers for the Retraction Boom" (https://www.thenewatlantis.com/publications/two-che ers-for-the-retraction-boom) (retrieven October 5, 2018)

8. Vuong, Q.-H. (2020). "Reform retractions to make them more transparent" (https://doi.org/1 0.1038\%2Fd41586-020-01694-x). Nature. 582 (7811): 149. doi:10.1038/d41586-020-01694-x (https://doi.org/10.1038\%2Fd41586-020-01694-x).

9. LaCroix, Travis; Geil, Anders; O'Connor, Cailin (2020). "The Dynamics of Retraction in Epistemic Networks" (https://www.journals.uchicago.edu/doi/abs/10.1086/712817).

Philosophy of Science. 88 (3): 415-438. doi:10.1086/712817 (https://doi.org/10.1086\%2F71 2817). ISSN 0031-8248 (https://www.worldcat.org/issn/0031-8248). S2CID 204791890 (http s://api.semanticscholar.org/CorpusID:204791890).

10. Séralini, Gilles-Eric; Clair, Emilie; Mesnage, Robin; Gress, Steeve; Defarge, Nicolas; Malatesta, Manuela; Hennequin, Didier; De Vendômois, Joël Spiroux (2012).

"RETRACTED: Long term toxicity of a Roundup herbicide and a Roundup-tolerant genetically modified maize" (https://doi.org/10.1016\%2Fj.fct.2012.08.005). Food and Chemical Toxicology. 50 (11): 4221-31. doi:10.1016/j.fct.2012.08.005 (https://doi.org/10.101 6\%2Fj.fct.2012.08.005). PMID 22999595 (https://pubmed.ncbi.nlm.nih.gov/22999595).

11. Torin Alter. "Jacksoon's Retraction" (https://web.archive.org/web/20080516091824/http://ww w.apa.udel.edu/apa/publications/proceedings/v76n3/public/abstracts.asp). APA. Archived from the original (http://www.apa.udel.edu/apa/publications/proceedings/v76n3/public/abstra cts.asp) on 2008-05-16.

12. Wu, Qiushi; Lu, Kangjie (2021-04-26). "Retraction of paper" (https://www-users.cs.umn.edu/ kjlu/papers/withdrawal-letter.pdf) (PDF). Retrieved 2021-05-02.

13. University of Minnesota, Department of Computer Science \& Engineering (2021-04-27). "Response Linux Foundation" (https://drive.google.com/file/d/1z3Nm2bfR4tH1nOGBpuOmL yoJVEiO9cUq/view). Retrieved 2021-05-02.

14. "Cornell finds that food marketing researcher Brian Wansink committed misconduct, as he announces retirement" (https://retractionwatch.com/2018/09/20/beleaguered-food-marketing -researcher-brian-wansink-announces-his-retirement-from-cornell/). Retraction Watch. 2018-09-20. Retrieved 2018-09-22.

15. "A Prominent Researcher on Eating Habits Resigned After a Scandal Over His Studies" (htt p://time.com/5402927/brian-wansink-cornell-resigned/). Time Inc. 2018-09-21. Retrieved 2018-09-22.

16. "This Ivy League food scientist was a media darling. He just submitted his resignation, the school says" (https://www.washingtonpost.com/health/2018/09/20/this-ivy-league-food-scien tist-was-media-darling-now-his-studies-are-being-retracted/). The Washington Post. 2018-09-20. Retrieved 2018-09-22.

17. "JAMA journals retract six papers by food marketing researcher Brian Wansink" (https://retra ctionwatch.com/2018/09/19/jama-journals-retract-six-papers-by-food-marketing-researcherbrian-wansink/). Retraction Watch. 2018-09-19. Retrieved 2018-09-22.

18. Oransky, Author Ivan (2018-12-05). "The Joy of Cooking, vindicated: Journal retracts two more Brian Wansink papers" (https://retractionwatch.com/2018/12/05/the-joy-of-cooking-vin dicated-journal-retracts-two-more-brian-wansink-papers/). Retraction Watch. Retrieved 2018-12-05. 
19. "Retraction Watch Database - Brian Wansink" (http://retractiondatabase.org/RetractionSearc h.aspx\#?auth\%3dWansink\%252c\%2bBrian). Retraction Watch. Retraction Watch. Retrieved 2019-01-22.

20. Elaine Lies (4 June 2014). "Japan researcher agrees to withdraw disputed stem cell paper" (https://www.reuters.com/article/us-japan-stemcells-researcher-idUSKBNOEF0SO2014060 4). Reuters. Retrieved 4 June 2014.

21. "STAP paper co-author Sasai commits suicide" (http://www.japantimes.co.jp/news/2014/08/ 05/national/embattled-stap-study-co-author-dies-after-apparent-suicide-bid/). The Japan Times. Retrieved 5 August 2014.

22. "Retraction: Enhanced Inhibition of Tumour Growth and Metastasis, and Induction of Antitumour Immunity by IL-2-IgG2b Fusion Protein" (https://doi.org/10.1111\%2Fj.1365-3083. 2011.02519.x). Scandinavian Journal of Immunology. 73 (3): 266. 2011.

doi:10.1111/j.1365-3083.2011.02519.x (https://doi.org/10.1111\%2Fj.1365-3083.2011.02519. X). PMID 21391334 (https://pubmed.ncbi.nlm.nih.gov/21391334). "The retraction has been agreed due to a finding of scientific misconduct within the laboratory where the experiments took place, and was brought to our attention by the scientific community."

23. "Misconduct in science : An array of errors" (http://www.economist.com/node/21528593). The Economist. 10 September 2011.

24. The Editors Of The Lancet (2010). "Retraction-lleal-lymphoid-nodular hyperplasia, nonspecific colitis, and pervasive developmental disorder in children". The Lancet. 375 (9713): 445. doi:10.1016/S0140-6736(10)60175-4 (https://doi.org/10.1016\%2FS0140-6736\%2810\% 2960175-4). PMID 20137807 (https://pubmed.ncbi.nlm.nih.gov/20137807).

S2CID 26364726 (https://api.semanticscholar.org/CorpusID:26364726). Lay summary (htt p://news.bbc.co.uk/2/low/health/8493753.stm) - BBC News (2010-02-02).

25. Mehra, Mandeep R.; Desai, Sapan S.; Ruschitzka, Frank; Patel, Amit N (2020-05-22). "RETRACTED: Hydroxychloroquine or chloroquine with or without a macrolide for treatment of COVID-19: a multinational registry analysis" (https://www.thelancet.com/journals/lancet/ar ticle/PIIS0140-6736(20)31180-6/fulltext). The Lancet. doi:10.1016/S0140-6736(20)31180-6 (https://doi.org/10.1016\%2FS0140-6736\%2820\%2931180-6). PMC 7255293 (https://www.n cbi.nlm.nih.gov/pmc/articles/PMC7255293). PMID 32450107 (https://pubmed.ncbi.nlm.nih.g ov/32450107). Archived (https://web.archive.org/web/20200607165329/https://www.thelanc et.com/journals/lancet/article/PIIS0140-6736(20)31180-6/fulltext) from the original on 2020-06-07. Retrieved 2020-06-07.

26. Boseley, Sarah (2020-06-04). "How were medical journals and WHO caught out over hydroxychloroquine?" (https://www.theguardian.com/world/2020/jun/03/how-were-medical-jo urnals-and-who-caught-out-over-hydroxychloroquine). The Guardian. Archived (https://web. archive.org/web/20200607165330/https://www.theguardian.com/world/2020/jun/03/how-wer e-medical-journals-and-who-caught-out-over-hydroxychloroquine) from the original on 2020-06-07. Retrieved 2999-12-31. Check date values in: । access-date= (help)

27. Boseley, Sarah; Davey, Melissa (2020-06-04). "Covid-19: Lancet retracts paper that halted hydroxychloroquine trials" (https://www.theguardian.com/world/2020/jun/04/covid-19-lancet-r etracts-paper-that-halted-hydroxychloroquine-trials). The Guardian. Archived (https://web.ar chive.org/web/20200607165614/https://www.theguardian.com/world/2020/jun/04/covid-19-la ncet-retracts-paper-that-halted-hydroxychloroquine-trials) from the original on 2020-06-07. Retrieved 2020-06-07.

28. https://retractionwatch.com/2020/07/08/retraction-of-paper-on-police-killings-and-race-notdue-to-mob-pressure-or-distaste-for-the-political-views-of-people-citing-the-workapprovingly-say-authors/ - Retraction of paper on police killings and race not due to "'mob' pressure" or "distaste for the political views of people citing the work approvingly," say authors 
29. Liu, Ming-Jin; Xiong, Cai-Hua; Xiong, Le; Huang, Xiao-Lin (January 5, 2016).

"Biomechanical Characteristics of Hand Coordination in Grasping Activities of Daily Living" (https://www.ncbi.nlm.nih.gov/pmc/articles/PMC4701170). PLOS ONE. 11 (1): e0146193. Bibcode:2016PLoSO..1146193L (https://ui.adsabs.harvard.edu/abs/2016PLoSO..1146193L) . doi:10.1371/journal.pone.0146193 (https://doi.org/10.1371\%2Fjournal.pone.0146193). PMC 4701170 (https://www.ncbi.nlm.nih.gov/pmc/articles/PMC4701170). PMID 26730579 (h ttps://pubmed.ncbi.nlm.nih.gov/26730579). (Retracted)

30. "Faith and Science Seeking Understanding: Reviewing \#Creatorgate - Blog Series" (http://bi ologos.org/blogs/kathryn-applegate-endless-forms-most-beautiful/series/reviewing-creatorg ate). BioLogos. 10 March 2016. Retrieved 2016-03-12.

\section{Further reading}

- Lesk, Michael (2015). "How many scientific papers are not original?" (https://www.ncbi.nlm.n ih.gov/pmc/articles/PMC4291619). Proceedings of the National Academy of Sciences. 112 (1): 6-7. Bibcode:2015PNAS..112...6L (https://ui.adsabs.harvard.edu/abs/2015PNAS..11 2...6L). doi:10.1073/pnas.1422282112 (https://doi.org/10.1073\%2Fpnas.1422282112). PMC 4291619 (https://www.ncbi.nlm.nih.gov/pmc/articles/PMC4291619). PMID 25538304 (https://pubmed.ncbi.nlm.nih.gov/25538304).

Retrieved from "https://en.wikipedia.org/w/index.php?title=Retractions_in_academic_publishing\& oldid=1044686449"

\section{This page was last edited on 16 September 2021, at 14:52 (UTC).}

Text is available under the Creative Commons Attribution-ShareAlike License; additional terms may apply. By using this site, you agree to the Terms of Use and Privacy Policy. Wikipedia ${ }^{\circledR}$ is a registered trademark of the Wikimedia Foundation, Inc., a non-profit organization. 